\title{
Mereduksi amonia kotoran ternak unggas dengan menggunakan kapur dan tanaman kedelai
}

\author{
Abustan $^{1 *}$, A. Pudjirahaju ${ }^{2}$ \\ 1Program Studi Pendidikan Fisika, Universitas Palangka Raya, Indonesia \\ 2Program Studi Ilmu Peternakan, Universitas Palangka Raya, Indonesia
}

\begin{abstract}
Abstrak.
Penelitian ini dilakukan untuk membantu masyarakat peternak di Kalimantan Tengah dalam mengatasi permasalahan tentang pencemaran udara yang sering dikeluhkan oleh warga masyarakat yang terdampak akibat adanya aktivitas peternakan di sekitar pemukiman karena munculnya bau berupa amonia yang ditimbulkan dari kotoran ternak serta banyak lalat yang beterbangan. Upaya mengatasi hal ini dilakukan dengan memanfaatkan kapur beserta tumbuhan kedelai untuk mengatasi pencemaran udara. Metode untuk mengetahui seberapa besar intensitas bau amonia dari setiap kandang ternak baik yang diberi perlakuan maupun yang tidak diberi perlakuan kesemuanya diukur dengan menggunakan alat detektor amonia model AR8500. Hasil penelitian menemukan bahwa pemberian kapur dan penanaman kedelai adalah suatu perlakuan yang paling tepat karena mampu menurunkan intensitas bau amonia hingga 64,07\%, dari 1,67 ppm (kandang kontrol tanpa perlakuan) menjadi 0,60 ppm. Selanjutnya disusul kandang dengan perlakuan pemberian kapur turun hingga 59,28\%, dari 1,67 ppm menjadi 0,68 ppm, serta penanaman kedelai di sekeliling kandang juga mampu menurunkan intensitas bau amonia hingga 53,29\% dari 1,67 ppm turun menjadi 0,78 ppm. Sementara dosis penggunaan kapur yang paling rasional baik ditinjau dari faktor ekonomi maupun fungsinya dalam menurunkan intensiatas bau amonia sebanyak $525 \mathrm{~kg}$ atau sekitar 0,88 kg/m². Angka ini setara dengan $\mathrm{Rp} 882 / \mathrm{m}^{2}$.
\end{abstract}

\begin{abstract}
.
This research was conducted to help the farmers in Central Kalimantan in overcoming the problems of air pollution; the smell of amonia gas as well as a large number of flies, both as a result of livestock manure, was often the source of complaint by local people, and affected from the activity of broiler farming around settlements. The researchers tried to use limestone and soybean plants to combat air pollution, and the intensity of the amonia gas odor from each cattle enclosure, both treated and untreated, were measured using the AR8500 amonia detector device. The results showed that lime and soybean was the most appropriate treatment, helping to reduce the intensity of ammonia gas odor up to $64.0 \%$, from $1.67 \mathrm{ppm}$ (control) to $0.60 \mathrm{ppm}$. Lime treatment alone was slightly less effective, reducing to $59.3 \%$, from 1.67 ppm to $0.68 \mathrm{ppm}$. Planting soybean around the enclosure was also able to reduce ammonia to 53.3\%, from $1.67 \mathrm{ppm}$ decreased to $0.78 \mathrm{ppm}$. The best dosage of lime used was 525 $\mathrm{kg}$ or $0.88 \mathrm{~kg} / \mathrm{m}^{2}$, which is equivalent to Rp.882 per $\mathrm{m} 2$.
\end{abstract}

Keywords: amonia, limestone, soybean, odor intensity

\section{PENDAHULUAN}

Perkembangan peternakan ayam boiler di Kalimantan Tengah khususnya di Palangka Raya cukup mengembirakan terutama dalam lima tahun terakhir ini, terlihat dari pemenuhan kebutuhan daging ayam broiler di Palangka Raya dan sekitarnya yang sudah mencapai 24 ton per hari atau sekitar 12.000 ekor. Menurut data Dinas Peternakan Provinsi Kalimantan Tengah (2015) angka ini mengalami kenaikan hingga 30\% jika dibandingkan dengan kebutuhan pada tahun 2011 yang lalu. Seiring dengan perkembangan kebutuhan daging ayam tersebut, juga tidak terlepas dengan persoalan yang dimunculkan dari aktivitas

\footnotetext{
${ }^{*}$ Korespondensi Penulis

Email : andi.bustan.99@gmail.com
} 
peternakan ini. Dampak negatif yang dapat ditimbulkan terhadap lingkungan pada proses produksi peternakan ayam biasanya dikaitkan dengan jumlah kotoran yang dihasilkan (Yusrini 2002).

Sebagian besar warga masyarakat yang bermukim di sekitar lokasi peternakan ayam broiler ini merasa terganggu oleh aktivitas peternakan karena munculnya aroma tidak sedap di saat-saat tertentu khususnya ketika ayam berumur 25 hingga 40 hari. Sumber utama aroma tidak sedap ini adalah kotoran yang dihasilkan oleh ternak unggas yang setiap harinya selalu bertambah seiring dengan bertambahnya umur ayam. Sebagai gambaran kotoran ternak yang dihasilkan untuk setiap ekor ayam hingga umur panen mencapai 0,5-0,8 $\mathrm{kg} /$ ekor, setara dengan $4.000 \mathrm{~kg}$ per 5.000 ekor ayam ternak. Angka ini akan semakin membesar jika dikalikan dengan jumlah kandang yang ada di lokasi peternakan, yang biasanya mencapai 4 buah atau sekitar 20.000 ekor di setiap lokasi atau terdapat $16.000 \mathrm{~kg}$ (16 ton) kotoran yang dihasilkan dalam satu periode pemeliharaan.

Lokasi peternakan didirikan di tempat yang relatif jauh dari pemukiman serta dianggap sangat aman dari aspek pencemaran udara, namun karena perkembangan penduduk termasuk perkembangan kebutuhan pemukiman yang pada akhirnya pemukiman bergeser mendekati lokasi peternakan. Hal ini tentu menimbulkan persolan baru baik peternak maupun warga yang bermukim di sekitar lokasi peternakan, inilah yang sering dialami oleh para peternak dan investor (mitra) yang menanamkan modalnya dalam agrobisnis ini.

Perkembangan pemukiman masyarakat di sekitar lokasi peternakan semakin padat, hal ini seiring dengan perkembangan dari waktu ke waktu. Gambaran umum saat ini bahwa jarak terdekat antara pemukiman dengan lokasi ternak sekitar 50-350 m. Jarak ini sangat dekat untuk terkena dampak pencemaran udara yang bersumber dari kotoran ayam ternak. Kondisi ini diperburuk dengan arah angin yang dapat membawa bau amonia ke pemukiman yang lebih jauh.

Persoalan ini dapat diatasi sebagai solusi jangka panjang yaitu mencari lokasi baru, dan kembali membangun kandang-kandang baru (relokasi), namun karena membangun kandang baru dengan kapasitas 5.000 ekor beserta segala kelengkapannya biayanya mencapai Rp 165.000 .000 biaya ini belum termasuk harga tanah, ini suatu angka yang cukup besar khususnya bagi peternak mandiri. Oleh karena itu, perlu ada pemikiran yang konstruktif untuk mengatasi permasalahan ini, karena terhentinya aktivitas pemeliharaan ayam boiler di suatu tempat, sudah pasti berdampak terhadap menurunnya produktivitas daging ayam yang berarti menurunnya pasokan daging ayam di pasaran.

Amonia bisa sangat beracun untuk berbagai organisme (Brigden dan Stringer 2000). Selain menimbulkan gangguan pernapasan pada manusia, juga 
ada persoalan yang selalu dihadapi oleh peternak yaitu angka kematian yang tinggi di umur 30 hingga 40 hari, kematian yang tinggi ini juga dipicu oleh tingginya intensitas bau dari bawah kandang, rata-rata ketinggian kandang dari permukaan tanah hanya sekitar $140 \mathrm{~cm}$ hingga $150 \mathrm{~cm}$. Hal ini berarti bahwa amonia $\left(\mathrm{NH}_{3}\right)$ atau kotoran ayam yang mengumpul di bawah kandang akan tercium secara bebas oleh ayam ternak yang berdampak pada penyakit saluran pernapasan ayam, sehingga menyebabkan tumbuh kembang ayam yang jauh dari ideal hingga pada kematian. Persoalan semacam inilah yang sangat diharapkan solusinya oleh masyarakat peternak agar dapat bekerja dengan tenang, dan produksi ternaknya tidak mengalami angka kematian yang tinggi. Angka kematian yang melewati $5 \%$ setiap periode pemeliharaan akan menyebabkan peternak mengalami kerugian yang tidak sedikit.

Secara spesifik munculnya amonia ini disebabkan oleh urea dan asam urat $\left(\mathrm{C}_{5} \mathrm{H}_{4} \mathrm{O}_{3} \mathrm{~N}_{4}\right)$ sebagai produk akhir metabolisme purin (Ngili 2009) dari hasil limbah kotoran/feses ayam yang belum mampu tertangani dengan baik. Kebanyakan kandang yang dibuat untuk peternakan di Palangka Raya berbentuk rumah panggung, sehingga memungkinkan kotoran dari ayam akan langsung jatuh ke tanah dan bercampur dengan unsur hara di dalamnya, biasanya lambat mengering, sehingga dapat meminimalkan bau racun amonia $\left(\mathrm{NH}_{3}\right)$, namun dalam beberapa kasus kondisi kandang seperti dijelaskan sebelumnya tidak mengurangi dampak yang ditimbulkan.

Menurut Rachmawati (2000), seekor ayam dalam sehari rata-rata menyumbangkan kotoran $0,15 \mathrm{~kg}$, dengan total nitrogen yang terkandung $\pm 2,94 \%$, yang dapat menjadi sumber amonia ketika kotoran lambat mengering karena kelembaban tinggi atau suhu yang lembab di bawah kandang. Pain (1999) menyebutkan bahwa gangguan bau dari sistem usaha peternakan sangat tinggi. Bau dari kotoran ternak merupakan hasil biotransformasi kotoran ternak oleh aktivitas bakteri baik secara aerob maupun anaerob. Tajamnya bau amonia yang dihasilkan dari kotoran ayam disebabkan kurangnya kemampuan bakteri nitrozomonas dan bakteri nitrobacter dalam reaksi nitrifikasi yaitu mengubah amonia kedalam senyawa nitrit $\mathrm{NO}_{2}$ - dan nitrat $\mathrm{NO}_{3}$ - (Marsidi 2002). Bakteri ini banyak terkandung dalam tanah yang subur dimana tumbuhan memproses alami proses nitrifikasi ini, namun berbeda halnya dengan tanah di Palangka Raya yang kategorinya tanah gambut, tingkat zat hara dan kesuburannya kurang (kondisi asam) serta kelembabannya yang tinggi karena kategori tanah berair sepanjang tahun dengan $\mathrm{pH}$ yang berbeda di setiap tempat, sehingga tanah tidak dapat memproses amonia ini dengan maksimal ketika kotoran ayam yang telah berubah menjadi amonia ini jatuh ke tanah karena bereaksi dengan air dan udara. 
Salah satu upaya untuk menurunkan bau amonia adalah dengan memanfaatkan kapur beserta tanaman polong-polongan (kacang kedelai) yang ditanam di pinggiran kandang, pemberian kapur ini dilakukan berdasarkan perbandingan luasan areal kandang yang ditempati kotoran ternak unggas. Pemilihan kapur dan tanaman kedelai ini setelah mempelajari lebih dalam tentang karakteristik kapur beserta tanaman kedelai sebagai bahan yang dapat digunakan untuk mempercepat proses pengeringan kotoran ternak yang selanjutnya diharapkan menurunkan kadar bau amonia.

\section{METODOLOGI}

\subsection{Lokasi Kajian dan Waktu Penelitian}

Penelitian dilaksanakan di lokasi peternakan yang berada di wilayah Kereng Bangkirai Kota Palangka Raya, terletak $9 \mathrm{~km}$ dari Universitas Palangkaraya. Penelitian dilaksanakan pada Februari-Juli 2017 dengan dua periode pengambilan sampel.

\subsection{Metode Penelitian}

Metode penelitian ini adalah metode eksperimental dengan teknik observasi di lapangan dan analisis laboratorium. Metode eksperimental dengan teknik observasi di lapangan dilakukan untuk mengumpulkan sampel kotoran ayam mulai dari ayam pertama kali masuk kandang sampai masa panen (35-40 hari). Sampel diambil 5 hari sekali setelah hari ke-12 (hari 1 sampai hari 12 kotoran ayam tidak jatuh ke tanah akan tetapi berada di atas serbuk kayu yang sudah dipersiapkan saat pembibitan) dengan 8 pengambilan tempat sampel berbeda ( 4 tempat sampel diberi perlakuan khusus dengan sekeliling kandang ditanami kedelai).

Pengambilan sampel kotoran ayam dilakukan pada dua tempat yaitu peternakan yang tanpa kedelai dan peternakan yang dikelilingi oleh kedelai. Perlakuan dua tempat ini dengan maksud menaksir daya serapan gas nitrogen pada kedelai, sehingga dapat diketahui kemampuan tanaman ini dalam mengurangi intensitas bau. Kedelai ditanam di seputaran kandang (ditanam dengan cara mengelilingi kandang ternak) yang luasnya mencapai $(4 \times 7) \mathrm{m}+$ $(4 \times 85) \mathrm{m}=36,8 \mathrm{~m}^{2}$. Tanaman ditanam seminggu sebelum kandang diisi bibit ayam, dengan asumsi tanaman telah tumbuh dengan sempurna sebelum kotoran ayam jatuh ke bawah kandang saat umur ayam 14 hari.

Kotoran diukur kadar amonia, kemudian diberi kapur yang sesuai, dengan cara dicairkan dan disemprotkan pada kotoran agar bau amonia hilang. Seminggu sekali dilakukan pengambilan sampel tanah di sekitar kedelai untuk menganalisis kandungan bakteri pengurainya. Pemberian kapur pada kotoran ayam dimulai saat umur ayam mencapai 20 hari, kotoran ayam pada umur ini relatif masih kurang (tebarannya) masih tipis dan belum memenuhi luasan 
kandang yang ada (ini terjadi pada ke empat kandang yang menjadi obyek pengamatan). Selanjutnya sistem penaburan kapur diberikan secara berturutturut pada umur 25, 30, 35 dan 40 hari.

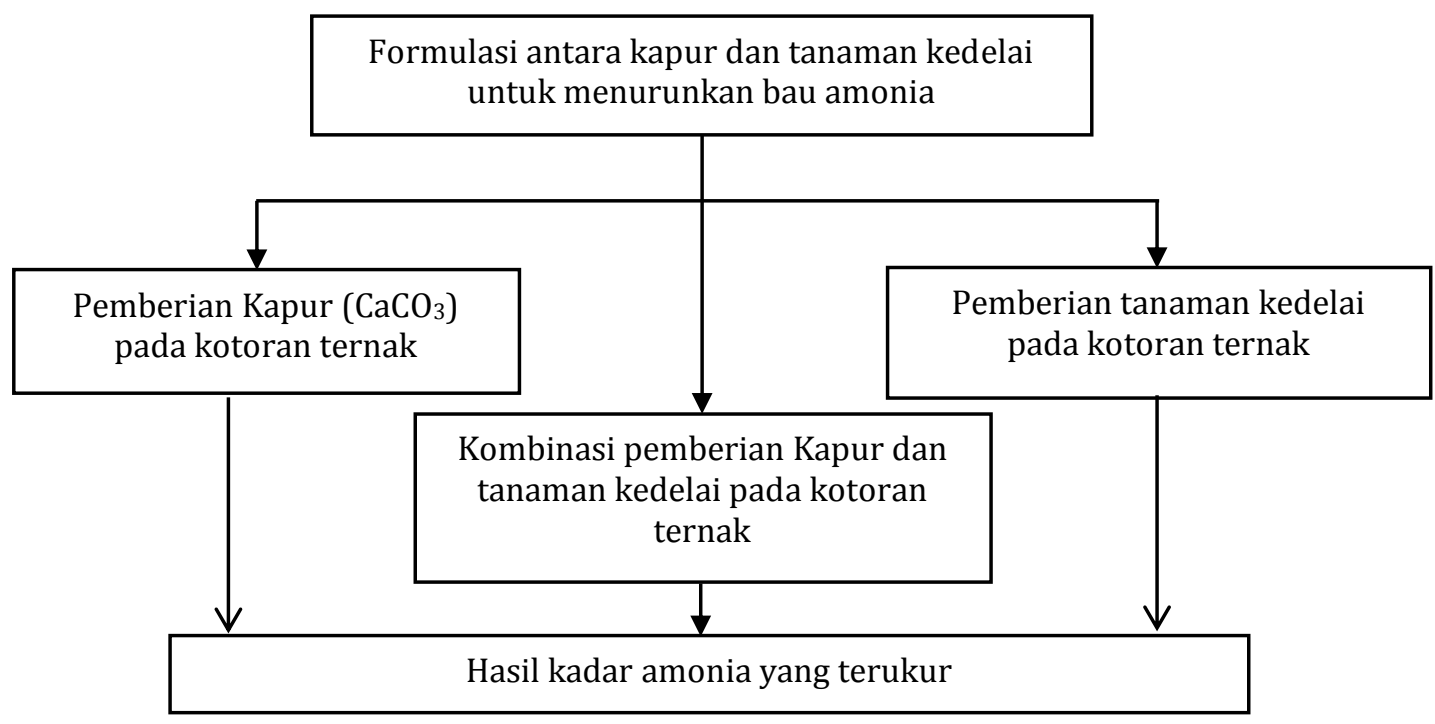

Gambar 1. Bagan proses penelitian.

Perlakuan pertama dengan menaburkan kapur sebanyak $25 \mathrm{~kg}$ pada luasan $65 \%$ dari luasan kandang $\left(595 \mathrm{~m}^{2}\right)$ dengan kapasistas ayam 5.000 ekor. Selanjutnya pengukuran kedua, ketiga, ke empat dan ke lima, penambahan komposisi kapur naik menjadi $50 \mathrm{~kg}, 100 \mathrm{~kg}, 150 \mathrm{~kg}$ dan $200 \mathrm{~kg}$, dengan cakupan luasan sudah mencapai $100 \%$ dari luas keseluruhan kandang. Setiap perlakuan yang diberikan selanjutnya dideteksi amonia yang ditimbulkan dengan menggunakan alat detektor seri A8500 pada 4 titik yaitu masing-masing $0 \mathrm{~m}, 25$ $\mathrm{m}$ dan $50 \mathrm{~m}$ dan $75 \mathrm{~m}$ dari sumber amonia atau dari kandang. Berikut ini merupakan gambar alur formulasi antara kapur dan tanaman kedelai yang digunakan untuk menurunkan bau amonia (Gambar 1).

\section{HASIL DAN PEMBAHASAN}

\subsection{Hasil penelitian}

3.1.1. Untuk kandang A : perlakuan yang diberikan adalah pemberian kapur

Hasil pengukuran amonia pada kandang A dengan jarak masing-masing 0 m, 25 m, 50 m dan $75 \mathrm{~m}$ dapat dilihat pada Tabel 1.

Tabel 1. Pengukuran amonia pada kandang A.

\begin{tabular}{|c|c|c|c|c|}
\hline & $0 \mathrm{~m}$ & $25 \mathrm{~m}$ & $50 \mathrm{~m}$ & $75 \mathrm{~m}$ \\
\hline 1. 20 hari & $0,10 \mathrm{ppm}$ & $0,00 \mathrm{ppm}$ & $0,00 \mathrm{ppm}$ & $0,00 \mathrm{ppm}$ \\
\hline 2. 25 hari & $0,13 \mathrm{ppm}$ & $0,00 \mathrm{ppm}$ & $0,00 \mathrm{ppm}$ & $0,00 \mathrm{ppm}$ \\
\hline
\end{tabular}




\begin{tabular}{llllll}
\hline & & $0 \mathrm{~m}$ & $25 \mathrm{~m}$ & $50 \mathrm{~m}$ & $75 \mathrm{~m}$ \\
\hline 3. & 30 hari & $0,21 \mathrm{ppm}$ & $0,00 \mathrm{ppm}$ & $0,00 \mathrm{ppm}$ & $0,00 \mathrm{ppm}$ \\
$4 . \quad 35$ hari & $0,37 \mathrm{ppm}$ & $0,13 \mathrm{ppm}$ & $0,00 \mathrm{ppm}$ & $0,00 \mathrm{ppm}$ \\
$5 . \quad 40$ hari & $0,68 \mathrm{ppm}$ & $0,33 \mathrm{ppm}$ & $0,16 \mathrm{ppm}$ & $0,00 \mathrm{ppm}$ \\
\hline
\end{tabular}

3.1.2. Kandang B : perlakuan dengan penanaman kedelai

Pada saat umur ayam mencapai 20 hari, pengukuran pertama dilakukan untuk melihat penyerapan kadar amonia $\left(\mathrm{NH}_{3}\right)$ yang ditimbulkan oleh kotoran ayam pada tanaman kedelai. Pada saat pengukuran pertama (minggu ke-4), kedelai memiliki ketinggian rata-rata $21,67 \mathrm{~cm}$, dengan jumlah daun berkisar 1014 lembar per pohon. Pada pengukuran yang kedua (minggu ke-5) tinggi tanaman rata-rata $23,5 \mathrm{~cm}$, dengan jumlah daun 14-18 lembar, pada pengukuran ketiga 27,5 cm, pengukuran keempat $30,8 \mathrm{~cm}$, dan pengukuran kelima $35,2 \mathrm{~cm}$, dengan jumlah daun 15-20 lembar, tidak termasuk daun yang sudah kering/layu. Pertumbuhan kedelai dengan jumlah daun dan pertumbuhan akar yang signifikan terhadap umur dan ketinggian tanaman diharapkan dapat menyerap amonia di sekitar kandang ternak. Data pengukuran amonia ditunjukkan pada Tabel 2.

Tabel 2. Pengukuran amonia pada kandang B.

\begin{tabular}{lllll}
\hline & $0 \mathrm{~m}$ & $25 \mathrm{~m}$ & $50 \mathrm{~m}$ & $75 \mathrm{~m}$ \\
\hline 1. 20 hari & $0,12 \mathrm{ppm}$ & $0,00 \mathrm{ppm}$ & $0,00 \mathrm{ppm}$ & $0,00 \mathrm{ppm}$ \\
2. 25 hari & $0,17 \mathrm{ppm}$ & $0,09 \mathrm{ppm}$ & $0,00 \mathrm{ppm}$ & $0,00 \mathrm{ppm}$ \\
3. 30 hari & $0,28 \mathrm{ppm}$ & $0,10 \mathrm{ppm}$ & $0,00 \mathrm{ppm}$ & $0,00 \mathrm{ppm}$ \\
4. 35 hari & $0,40 \mathrm{ppm}$ & $0,23 \mathrm{ppm}$ & $0,10 \mathrm{ppm}$ & $0,00 \mathrm{ppm}$ \\
5. 40 hari & $0,78 \mathrm{ppm}$ & $0,48 \mathrm{ppm}$ & $0,28 \mathrm{ppm}$ & $0,03 \mathrm{ppm}$ \\
\hline
\end{tabular}

Perlakuan terhadap kandang B yang hanya ditanami kedelai tanpa ada perlakuan lain menunjukkan intensitas amonianya relatif masih lebih tinggi dibandingkan dengan pemberian kapur, bahkan data tersebut menunjukkan angka yang cukup jauh melampaui ambang batas yang ditentukan berdasarkan Peraturan Menteri Lingkungan Hidup No. 21 Tahun 2008 tentang baku mutu terhadap sumber yang tidak bergerak bagi usaha. Batas ambang amonia $\left(\mathrm{NH}_{3}\right)$ adalah 0,5 ppm. Sementara yang dapat dijadikan sebagai kegiatan, terkait pemeliharaan ternak ini, pada usia 40 hari atau usia panen. Pada usia 40 hari kotoran yang ada di bawah kandang jumlahnya mencapai maksimal 250 karung $(5.000 \mathrm{~kg})$ selama pemeliharaan. Kotoran ayam tersebar merata di permukaan tanah di bawah kandang dengan tingkat penyebaran mencapai $8,40 \mathrm{~kg} / \mathrm{m}^{2}$, untuk luasan kandang sebesar $595 \mathrm{~m}^{2}$. Hasil penelitian dengan menggunakan tanaman kedelai di sekeliling kandang seluas 36,8 $\mathrm{m}^{2}$ ditunjukkan bahwa pemanfaatan kedelai masih belum memberikan hasil yang lebih baik jika dibandingkan dengan pemberian kapur. 
3.1.3 Kandang C: perlakuan dengan pemberian kapur yang disertai penanaman kedelai

Perlakuan yang diberikan pada kandang ternak ini ada dua macam yaitu penaburan kapur dan penanaman kedelai di seputar kandang. Luas tanaman kedelai di kandang $\mathrm{C}$ sama dengan luas tanaman kedelai di kandang B yaitu 36,8 $\mathrm{m}^{2}$, demikian juga komposisi kapur yang diberikan sama banyaknya pada kandang A. Oleh karena proses persiapan biji kedelai dan penanamanya dilakukan secara bersamaan dengan kandang B, maka tidak ada perbedaan secara signifikan tinggi tanaman kedelai rata-rata termasuk jumlah daun yang masih hijau, meski di beberapa area dijumpai beberapa tanaman yang kurang berkembang dengan baik disebabkan terdapatnya sarang semut dan dimakan oleh burung bagian daunnya. Nilai amonia dapat dilihat pada Tabel 3.

Tabel 3. Pengukuran amonia pada kandang $C$.

\begin{tabular}{lllll}
\hline & $0 \mathrm{~m}$ & $25 \mathrm{~m}$ & $50 \mathrm{~m}$ & $75 \mathrm{~m}$ \\
\hline 1. 20 hari & $0,09 \mathrm{ppm}$ & $0,00 \mathrm{ppm}$ & $0,00 \mathrm{ppm}$ & $0,00 \mathrm{ppm}$ \\
2. 25 hari & $0,11 \mathrm{ppm}$ & $0,06 \mathrm{ppm}$ & $0,00 \mathrm{ppm}$ & $0,00 \mathrm{ppm}$ \\
3. 30 hari & $0,22 \mathrm{ppm}$ & $0,10 \mathrm{ppm}$ & $0,00 \mathrm{ppm}$ & $0,00 \mathrm{ppm}$ \\
4. 35 hari & $0,40 \mathrm{ppm}$ & $0,22 \mathrm{ppm}$ & $0,07 \mathrm{ppm}$ & $0,00 \mathrm{ppm}$ \\
5. 40 hari & $0,60 \mathrm{ppm}$ & $0,38 \mathrm{ppm}$ & $0,15 \mathrm{ppm}$ & $0,00 \mathrm{ppm}$ \\
\hline
\end{tabular}

Jika mencermati data tersebut di atas, terlihat bahwa ada penurunan data pada setiap pengukuran yang dilakukan, namun pengukuran itu tidak terlalu signifikan dengan hasil pengukuran pada kandang kedua.

3.1.4. Kandang D : kandang kontrol tanpa ada perlakuan

Kandang ternak D dijadikan sebagai kandang kontrol, kandang ini tidak diberikan perlakuan apapun (dibiarkan pada kondisi apa adanya). Namun pengukuran amonia tetap dilakukan secara bersamaan dengan kandang A, B, dan C. Hasil pengukuran amonia pada kandang D ditunjukkan pada Tabel 4.

Tabel 4. Pengukuran amonia pada kandang D.

\begin{tabular}{lcccc}
\hline & $0 \mathrm{~m}$ & $25 \mathrm{~m}$ & $50 \mathrm{~m}$ & $75 \mathrm{~m}$ \\
\hline $1 .(20$ hari) & $0,14 \mathrm{ppm}$ & $0,07 \mathrm{ppm}$ & $0,02 \mathrm{ppm}$ & $0,00 \mathrm{ppm}$ \\
$2 .(25$ hari) & $0,35 \mathrm{ppm}$ & $0,11 \mathrm{ppm}$ & $0,07 \mathrm{ppm}$ & $0,00 \mathrm{ppm}$ \\
$3 .(30$ hari) & $0,63 \mathrm{ppm}$ & $0,32 \mathrm{ppm}$ & $0,09 \mathrm{ppm}$ & $0,00 \mathrm{ppm}$ \\
$4 .(35$ hari) & $1,13 \mathrm{ppm}$ & $0,87 \mathrm{ppm}$ & $0,28 \mathrm{ppm}$ & $0,00 \mathrm{ppm}$ \\
$5 .(40$ hari) & $1,62 \mathrm{ppm}$ & $1,21 \mathrm{ppm}$ & $0,67 \mathrm{ppm}$ & $0,02 \mathrm{ppm}$ \\
\hline
\end{tabular}

Kandang D juga memiliki luas yang sama dengan kandang A, B, dan C dengan kapasitas ternak ayam yang bisa ditampung mencapai 5.000 ekor. Tidak ada perbedaan jumlah kapasitas ternak dari semua kandang yang ada. Namun bila dicermati dari hasil pengukuran alat detektor amonia terlihat bahwa pada 
usia ayam 30 hari kotoran ternak yang ada di bawah kandang, amonia yang dihasilkan sudah melewati standar baku mutu, bahkan pada radius $25 \mathrm{~m}$ ketika umur ternak ayam mencapai 35 hari juga sudah melampauhi ambang batas. berdasarkan Permen Lingkungan Hidup No. 21 tahun 2008 yang besarnya hanya 0,5 ppm. Terlebih lagi ketika usia ternak mencapai 40 hari, amonia yang ditimbulkan dapat terdeteksi pada radius $75 \mathrm{~m}$ (Tabel 5).

Tabel 5. Perbandingan bau amonia dari keempat sampel kandang pada umur ternak 40 hari.

\begin{tabular}{ccccc}
\hline & $0 \mathrm{~m}$ & $25 \mathrm{~m}$ & $50 \mathrm{~m}$ & $75 \mathrm{~m}$ \\
\hline Kd. A & $0,68 \mathrm{ppm}$ & $0,33 \mathrm{ppm}$ & $0,06 \mathrm{ppm}$ & - \\
Kd. B & $0,78 \mathrm{ppm}$ & $0,48 \mathrm{ppm}$ & $0,28 \mathrm{ppm}$ & $0,03 \mathrm{ppm}$ \\
Kd. C & $0,60 \mathrm{ppm}$ & $0,38 \mathrm{ppm}$ & $0,15 \mathrm{ppm}$ & - \\
Kd. D & $1,67 \mathrm{ppm}$ & $1,21 \mathrm{ppm}$ & $0,67 \mathrm{ppm}$ & $0,52 \mathrm{ppm}$ \\
\hline
\end{tabular}

Berdasarkan Tabel 5, diketahui bahwa komposisi yang ideal di dalam pemberian kapur pada lokasi peternakan (di bawah kandang) adalah $200 \mathrm{~kg}$ kapur per luasan kandang $\left(0,34 \mathrm{~kg} / \mathrm{m}^{2}\right)$ dengan kapasitas kandang mencapai 5.000 ekor. Dikatakan ideal karena bila dilihat dari nilai ekonomisnya, harga kapur sebanyak $200 \mathrm{~kg}$ (empat karung) adalah sebesar Rp 200.000 mampu menekan atau menurunkan intensitas bau amonia sebesar $40,71 \%$ yang artinya bahwa jika peternak yang kapasitas kandang nya 5.000 ekor ayam dengan luas kandang sebesar $595 \mathrm{~m}^{2}$, bilamana menggunakan kapur (menabur kapur di permukaan kotoran ayam) mampu menurunkan bau amonia sebesar 40,71\%. Sementara jika menggunakan komposisi $150 \mathrm{~kg}$ kapur, dengan luas sebaran 0,25 $\mathrm{kg} / \mathrm{m}^{2}$, walaupun ini dari segi harga relatif lebih murah, tidak dapat dijadikan sebagai patokan karena pada saat itu umur ayam masih 35 hari dengan berat badan baru mencapai 0,9 kg hingga 1,10 kg/ekor (kategori ayam kalasan).

Tabel 6. Sebaran penggunaan kapur tiap $\mathrm{m}^{2}$ yang ditaburkan di bawah kandang A dan C.

\begin{tabular}{ccccc}
\hline No & Luas permukaan & Jumlah kapur & Distribusi $/ \mathrm{m}^{2}$ & Jarak 0 m \\
\hline 1. & $357 \mathrm{~m}^{2}(60 \%)$ & $25 \mathrm{~kg}$ & $0,07 \mathrm{~kg} / \mathrm{m}^{2}$ & $0,1 \mathrm{ppm}$ \\
2. & $476 \mathrm{~m}^{2}(80 \%)$ & $50 \mathrm{~kg}$ & $0,11 \mathrm{~kg} / \mathrm{m}^{2}$ & $0,13 \mathrm{ppm}$ \\
3. & $595 \mathrm{~m}^{2}(100 \%)$ & $100 \mathrm{~kg}$ & $0,17 \mathrm{~kg} / \mathrm{m}^{2}$ & $0,21 \mathrm{ppm}$ \\
4. & $595 \mathrm{~m}^{2}(100 \%)$ & $150 \mathrm{~kg}$ & $0,25 \mathrm{~kg} / \mathrm{m}^{2}$ & $0,37 \mathrm{ppm}$ \\
5. & $595 \mathrm{~m}^{2}(100 \%)$ & $200 \mathrm{~kg}$ & $0,34 \mathrm{~kg} / \mathrm{m}^{2}$ & $0,68 \mathrm{ppm}$ \\
\hline
\end{tabular}

Komposisi kapur yang paling banyak ditaburkan saat mencapai usia panen pada umur 40 hari. Dengan luasan kandang $595 \mathrm{~m}^{2}$ jumlah kapur yg ditaburkan mencapai $200 \mathrm{~kg}$ atau sekitar $0,34 \mathrm{~kg} / \mathrm{m}^{2}$ (Tabel 6), setara dengan Rp 340 per $\mathrm{m}^{2}$, ini baru perhitungan pemberian kapur pada usia ke 40 hari. Akan tetapi bilamana data pemberian kapur untuk sekali pemeliharaan, maka jumlah kapur yang ditaburkan mencapai $525 \mathrm{~kg}$, atau sama dengan $0,88 \mathrm{~kg} / \mathrm{m}^{2}$, setara dengan Rp 882 per $\mathrm{m}^{2}$. 


\subsection{Pembahasan}

Dalam lima kali pemberian kapur yang ditaburkan pada permukaan tanah di bawah kandang A dan C yang dimulai pada umur 20, 25, 30, 35 dan 40 hari, dan disertai dengan pengukuran intensitas bau amonia ternyata memunculkan hasil pengukuran yang berbeda pada jumlah hari pengukuran yang sama. Perbedaan ini karena banyaknya kotoran ternak yang jatuh di bawah kandang seiring dengan bertambahnya umur ayam, dan pemberian perlakuan yang berbeda. Banyaknya kotoran ayam di bawah kandang seiring dengan pertambahan umur ayam dan jumlah pakan akan semakin menebalnya lapisan kotoran ayam di bawah kandang yang menutupi permukaan tanah. Lapisan yang menebal ini akan terekam dengan baik oleh alat ukur gas amonia. Ada perbedaan amonia di setiap pengukuran pada hari yang berbeda, hal ini disebabkan oleh perbedaan perlakuan.

Sebaran kapur yang diberikan di bawah kandang berbeda pada setiap waktu pengukuran hal ini dimaksudkan untuk tetap memperhitungkan faktor efisiensi (yang berhubungan dengan dana yang dikeluarkan oleh peternak) karena pemberian kapur yang berlebihan berdampak pada jumlah pengeluaran yang tinggi, dan jika ini terjadi berarti akan mengurangi pendapatan peternak. Pemberian kapur yang banyak justru lebih bagus untuk menghilangkan atau menurunkan amonia di kandang ternak, namun hal ini akan sulit dilakukan oleh peternak karena setiap m persegi kapur yang disebarkan oleh peternak sampai usia panen mencapai $525 \mathrm{~kg}$ atau dengan harga Rp 1.000/kg. Atau sekitar Rp 525.000 angka ini cukup berat bagi peternak, terlebih lagi jika ditambah dosis kapur yang diberikan sesuai Tabel 6.

Mencermati data yang dipaparkan pada Tabel 6, dari ke empat kandang ayam yang dijadikan sebagai lokasi penelitian, terlihat bahwa semua kandang pada usia ternak mencapai 40 hari atau usia panen kotoran ternak ayam atau amonia yang ditimbulkan semuanya berada di atas ambang batas baku mutu, khususnya pada pengukuran di pusat sumber amonia pada jarak $(0 \mathrm{~m})$. Intensitas bau amonia ini berkurang seiring dengan bertambahnya jarak pengukuran dengan pusat sumber amonia. Walaupun demikian tidak ada hasil pengukuran yang melampaui standar baku mutu di jarak titik pengukuran $25 \mathrm{~m}$, 50 m, dan 75 m, kecuali pada obyek penelitian di kontrol. Pada kontrol dijarak 75 m sudah mulai terdeteksi bau amonia walaupun intensitasnya masih rendah sekitar 0,05 ppm. Intensitas bau amonia ini semakin tinggi semakin mendekati kandang. Pada jarak $50 \mathrm{~m}$ dari pusat sumber, amonia mencapai 0,67 ppm, berada di atas ambang batas. Selanjutnya pada jarak $25 \mathrm{~m}$, amonia yang terdeteksi mencapai 1,21 ppm, di pusat sumber hingga 1,67 ppm.

Hal yang tidak kalah pentingnya untuk dicermati adalah perlakuan yang diberikan pada kandang B dimana pada tempat ini tidak ada pemberian kapur di 
bawah kandang akan tetapi yang dilakukan adalah penanaman tanaman kedelai seluas $(4 \times 7) \mathrm{m}+(4 \times 85) \mathrm{m}=368 \mathrm{~m}^{2}$ di sekeliling lokasi peternakan. Tumbuhan ini diharapkan mampu menurunkan amonia yang muncul akibat kotoran ternak.

Alasan pemanfaatan tanaman kedelai (tanaman polong-polongan) karena tananam ini bersimbiosis dengan bakteri nitrogen atau dikenal juga sebagai bakteri pengikat nitrogen salah satunya Rhizobium sebagai kelompok bakteri yang mampu mengikat nitrogen bebas di udara dan mereduksinya menjadi senyawa amonium $\left(\mathrm{NH}_{4}\right)$, ion nitrit $\left(\mathrm{NO}_{2}-\right)$ dan ion nitrat $\left(\mathrm{NO}_{3}-\right)$ dengan bantuan enzim nitrogenase.

Salah satu contoh tanaman polong-polongan adalah kedelai yang merupakan tanaman pangan berupa semak yang tumbuh tegak yang memiliki jenis akar tunggang, akar lateral, dan akar serabut. Rhizobium yang dapat menodulasi tanaman kedelai secara efektif dikenal sebagai Bradyrhizoium japonicum. Asosiasi simbiotik tanaman kedelai dengan bakteri B. japonicum dapat memfiksasi $\mathrm{N}$ diatas $200 \mathrm{~kg} \mathrm{~N} / \mathrm{ha} /$ tahun. Kebutuhan $\mathrm{N}$ pada tanaman kedelai dapat disuplai melalui fiksasi nitrogen biologi dengan memilih galurgalur B. japonicum yang efektif (Javaid dan Nasir 2010).

Tumbuhan kedelai jauh lebih murah ongkosnya dibandingkan dengan kapur sebagai sarana untuk menurunkan bau amonia di lokasi ternak, karena jenis tumbuhan ini relatif lebih mudah didapat dipasaran, harganya lebih murah, dan menanamnya juga mudah, yang penting lokasi menanam kedelai itu sudah dibersihkan dari rumput sehingga memudahkan pertumbuhannya. Tanaman ini juga bisa memberikan nilai tambah pada peternak karena tanaman kedelai bisa dimanfaatkan untuk sayuran. Hanya saja tanaman ini rentan dengan semut merah. Bilamana semut merah yang biasa muncul di tanaman kedelai ini khususnya saat baru penanaman tidak diantisipasi maka pertumbuhan tanaman kedelai bisa mati, atau kerdil.

Hal lain yang juga menjadi kendala jika tanaman kedelai yang dijadikan bahan penelitian dalam menurunkan amonia yaitu pada saat musin hujan pertumbuhan tanaman ini tidak bagus atau tidak bisa tumbuh dengan sempurna, dan kalaupun tumbuh pasti tidak sampai hingga 50\%. Tanaman kedelai yang pertumbuhannya terganggu karena hujan (keadaan tanah selalu lembab), proses penyerapan amonia hingga ke akar (ditandai dengan munculnya bintil akar) tidak bisa berjalan dengan baik, bahkan mungkin tidak terjadi proses penyerapan amonia.

Penyerapan amonia dengan memanfaatkan tumbuhan kedelai bilamana tumbuh dengan subur ditandai dengan munculnya bintil-bintil atau kumpalankumpalan kecil pada akar yang menandakan bahwa proses penyerapan amonia pada tumbuhan tersebut dapat terserap. Bintil akar ini merupakan bengkakan jaringan akar tumbuhan yang berisi bakteri. Semakin banyak kandungan N pada 
bintil akar, dapat meningkatkan proses fiksasi $\mathrm{N}$ yang memberikan nutrisi secara langsung untuk perkembangan tumbuhan (Carter dan Tegeder 2015). Dalam hal ini bakteri yang berperan dalam fiksasi $\mathrm{N}$ mendapatkan karbohidrat dalam jaringan akar, sedangkan tumbuhan memanfaatkan sebagian bahan bernitrogen yang dibuat oleh bakteri dari nitrogen dalam udara yang ada di atas partikel tanah (Ramdana dan Retno 2015).

Didik et al. (2004) menyebutkan bahwa legum dengan bintil akar dapat memanfaatkan baik gas nitrogen dari udara maupun nitrogen anorganik dari dalam tanah, yang berarti semakin lama tanaman ini tumbuh di sekitar kandang dan membiarkan proses penyerapan amonia pada kotoran ayam yang jatuh ke tanah itu secara alami maka semakin banyak pula bintil-bintil yang terdapat di akar tanaman tersebut. Namun karena penelitian berlangsung di musim hujan, keadaan tanah lembab dan basah sepanjang hari, sehingga pertumbuhan kedelai kurang maksimal yang berimbas pada berkurangnya kemampuan tanaman menyerap amonia yang terakumulasi dalam tanah. Dugaan ini didukung oleh Didik et al. (2004) yang menyatakan bahwa penyerapan nitrogen menurun terutama karena akar bagian bawah yang berada dalam tanah jenuh air dan mati, sehingga luas permukaan akar menurun.

Pada kandang $\mathrm{B}$ yang secara keseluruhan ditanami dengan tumbuhan kedelai di sekeliling kandang ternak tanpa ada perlakuan lainnya hasilnya tidak lebih bagus dari hasil penelitian di kandang A yang diberikan kapur. Walaupun hasil deteksi dari alat detektor pada pusat sumber bau amonia tidak ada yang di bawah standar baku mutu, akan tetapi data yang ditunjukkan oleh perlakuan pemberian kapur masih lebih baik daripada hanya penanaman kedelai. Bahkan pada kandang B yang ditanami kedelai di pinggiran kandang intensitas baunya masih bisa terdeteksi pada jarak $75 \mathrm{~m}$ dari pusat sumber bau amonia.

Kombinasi antara pemberian kapur dengan kedelai, hasil yang diperoleh juga tidak terlalu jauh berbeda dengan hasil perolehan data di kandang A. Intensitas bau amonia pada pusat sumber hanya berbeda tipis yakni 0,02 ppm. Pengukuran di lokasi pemberian kapur pada pusat sumber diperoleh 0,68 ppm, sementara hasil pengukuran di kandang $C$ yang dikombinasi dengan kedelai ditambah kapur didapat 0,60 ppm. Artinya hanya selisih 0,08 ppm lebih rendah dari hanya pemberian kapur saja.

Ada hal yang perlu dicermati pada data pengukuran di jarak $50 \mathrm{~m}$ dari sumber yaitu pada kandang A terdeteksi $0,06 \mathrm{ppm}$, sementara pada kandang $C$ dengan jarak yang sama terdeteksi sebesar 0,15 ppm. Data ini dapat dikatakan anomali karena seharusnya jika dicermati semua data yang ada diatas pada setiap kandang intensitas amonia dari kandang $C$ itu harusnya lebih rendah dari nilai kandang A tapi tidak demikian halnya. Hal ini karena pada saat pengukuran 
dilakukan, faktor arah pergerakan udara tidak dapat dielakkan sehingga arah angin perlu menjadi pertimbangan.

\section{KESIMPULAN DAN SARAN \\ 4.1. Kesimpulan}

Amonia yang ditimbulkan oleh kotoran ayam pada lokasi peternakan dapat diturunkan dengan kapur $\left(\mathrm{CaCO}_{3}\right)$ yang ditaburkan secara merata dengan bobot, $25 \mathrm{~kg}, 50 \mathrm{~kg}, 100 \mathrm{~kg}, 150 \mathrm{~kg}$ dan $200 \mathrm{~kg}$. Pemberian kapur secara bertahap pada setiap lima hari yang terhitung mulai pada usia ternak 20 hari. Pemberian kapur pada kotoran ternak mampu menekan intensitas bau amonia dari 1,67 ppm (data acuan tanpa perlakuan) menjadi $0,68 \mathrm{ppm}$ atau sekitar $40,71 \%$ pada titik sumber amonia, yang berarti bahwa dengan pemberian kapur akan menekan amonia sebesar $59,28 \%$.

Pemberian kedelai di sekeliling kandang juga mampu menurunkan intensitas bau amonia dari 1,67 ppm menjadi 0,78 ppm atau sekitar 46,70\% pada titik sumber amonia, yang berarti bahwa dengan penanaman kedelai akan dapat menghilangkan amonia sebesar 53,29\%. Kombinasi antara pemberian kapur dan penanaman kedelai pada kandang $\mathrm{C}$ juga mampu menurunkan intensitas bau amonia dari 1,67 menjadi $0,60 \mathrm{ppm}$, atau sekitar 35,93\% pada titik sumber amonia, yang berarti bahwa dengan kombinasi kapur serta kedelai mampu mengilangkan bau amonia sebesar 64,07\%.

Komposisi kapur yang paling tepat ditinjau dari aspek ekonomi serta kemampuannya menurunkan amonia pada kotoran ternak ayam sebanyak 525 kg dengan luas kandang hingga $595 \mathrm{~m}^{2}$, untuk lima kali pemberian secara bertahap pada kandang yang berkapasitas 5000 ekor. Jumlah kapur ini adalah jumlah yang masih mampu dilakukan atau diadakan oleh peternak. Dari hasil pengukuran pada alat detektor, setelah diberi perlakuan baik pemberian kapur pada kotoran ternak, penanaman kedelai, maupun kombinasi dari kedua unsur ini ditemukan bahwa pada jarak $25 \mathrm{~m}$ ke atas tidak ada amonia yang mencapai ambang batas baku mutu amonia sebesar 0.55 .

\subsection{Saran}

Perlu ada pemilihan bibit kedelai sebelum disemai agar pertumbuhannya lebih baik dan tidak menjadi kerdil khususnya disaat saat umur ayam mencapai 20 hari, saat awal pengukuran pertama dilakukan. Perlu diperhitungkan arah angin dan temperatur udara ketika pengukuran karena hal ini sangat mempengaruhi alat detektor. Hal ini menunjukkan bahwa pengukuran amonia dikemudian hari harusnya sudah ada peralatan tentang pengukuran kecepatan udara (arah angin) yang disiapkan. 


\section{Daftar Pustaka}

Brigden K and Stringer R. 2000. Amonia and urea production: incidents of amonia release from the profertil urea and amonia facility, Bahia Blanca, Argentina. Greenpeace Research Laboratories, Departement of Biological Science University of Exeter. United Kingdom.

Carter AM and Tegeder M. 2015. Increasing nitrogen fixation and seed development in soybean requires complex adjustments of nodule nitrogen metabolism and partitioning processes. Current Biology 26(15):20442051.

Didik I, Soemartono S, Notohadisuwarno S and Hari P. 2004. Metabolisme nitrogen pada tanaman kedelai yang mendapat genangan dalam parit. Jurnal Ilmu Pertanian 11(2):68-75.

Javaid A and Nasir M. 2010. Growth, nodulation and yield response of soybean to biofertilizers and organic manures. Journal of Botany 42(2):863-871.

Marsidi R. 2002. Proses nitirifikasi dengan sistem biofilter untuk pengolahan air limbah yang mengandung amoniak konsentrasi tinggi. Jurnal Teknologi Lingkungan 3(3):195-204.

Ngili Y. 2009. Biokimia metabolisme \& bioenergitika. Graha Ilmu. Yogyakarta.

Pain BF. 1999. Gangguan bau yang berasal dari sistem produksi ternak, in pollution in livestock production system. IKIP Semarang Press. Semarang.

Rachmawati S. 2000. Upaya pengelolaan lingkungan usaha peternakan ayam. Wartazoa 9(2):73-80.

Ramdana S dan Retno P. 2015. Rhizobium: pemanfaatannya sebagai bakteri penambat nitrogen. E-Journal Teknis EBONI 12(1):51-64.

Yusrini H. 2002. Penangkapan dan pengukuran amonia pada kotoran ayam. Balai Penelitian Veteriner. Bogor. 